\title{
Studies on Fresh Water Microalgae Harvesting Systems for Bio Fuel
}

\author{
Anil K. Dubey ${ }^{1}$, Swapnaja K. Jadhav ${ }^{1}$, Ankur Nagori ${ }^{1}$, Mayuri Gupta ${ }^{2}$, \\ Parmanand Sahu ${ }^{2}$ and Sujata Tayade ${ }^{2}$ \\ ${ }^{1}$ Central Institute of Agricultural Engineering, Bhopal, India \\ ${ }^{2}$ Consortia Research Platform on Energy in Agriculture, CIAE, Bhopal, India \\ *Corresponding author
}

\begin{tabular}{l} 
Ke y w o r d s \\
$\begin{array}{l}\text { Fresh water, } \\
\text { Microalgae, } \\
\text { Harvesting systems, } \\
\text { Bio fuel }\end{array}$ \\
Article Info \\
$\begin{array}{l}\text { Accepted: } \\
22 \text { November } 2020 \\
\text { Available Online: } \\
10 \text { December } 2020\end{array}$ \\
\hline
\end{tabular}

\section{A B S T R A C T}

\section{Introduction}

The importance of microalgae and their valuable products has significantly increased in the fields of human health, food, feed and biofuels. The recovery of microalgae biomass from solution is a major challenge, largely due to the small biomass concentration relative to the volume of liquid and low biomass to liquid ratio $(0.3$ to $5.0 \mathrm{~g} / \mathrm{L})(\mathrm{Li}$, et al., 2008 and Wang, et al., 2008). The technology used for the recovery of microalgae biomass is considered to have a major influence on the economy of microalgae production (Danquah et al., 2009 and Brennan and Owende, 2010). As yet, none of the commonly available technologies has proved economical at scale. The main harvesting techniques are centrifugation; filtration; flocculation; sedimentation; and 
electrophoresis (Schenk, et al., 2008 and Grima, et al., 2003). Centrifugal process of harvesting of algal is the fastest and most reliable method of biomass recovery for a wide range of species but high energy intensive.

Filtration is common practice, but it dependents on the size of the microalgae being harvested. The low recovery rate and long processing times makes filtration process unattractive at large scale. Likewise, flocculation is also uneconomical and most effective commercial flocculants are aluminum sulphate and some specific organic cationic polyelectrolyte flocculants (Uduman et al., 2010) Gravity sedimentation is time consuming and requires large land areas for settling ponds and tanks. Electro coagulation and electro flotation makes the electrochemical oxidation of metal electrode to destabilize algae suspensions causing the cells to float. Foam flotation is a process for removing surface active chemicals from water and dewatering dilute solid liquid mixtures (Lehmonen et al., 2019). Considering the limitations of different harvesting systems and importance study is initiated to evaluate the different harvesting process to develop cost effective harvesting system.

\section{Micro algae harvesting studies}

The recovery of microalgae is considered to have the most influential effect on the economy of microalgae production system (Monteiro et al., 2012). The selection of harvesting technology is depends on type of cell, density \& size, downstream processing and the end product (Borowitzka, 2013). The harvesting techniques which have been developed since past four decades are categorized into two i.e. i) Primarily bulk harvesting of the algae to increase the concentration by $2-7 \%$ in total suspended solids (TSS). This is achieved with the use of flocculation, floatation or sedimentation process. ii) The secondary process followed for dewatering step of microalgae, which produces biomass up to $15-25 \%$ TSS, this is achieved with filtration or centrifugation which is energy intensive processes as compared to primary process (Olaizola, 2000 and Uduman et al., 2010).

\section{Sedimentation}

Solid liquid partitioning by sedimentation is one of the simplest ways to harvest microalgae.

It separates the suspended algae cells having a cell density greater than water by gravitational settling. The operating and capital costs are low, but space requirement for settling ponds and tanks are high. The ambient conditions during harvesting such as high temperature of environments deteriorate the biomass produced due to lengthy harvesting process. Conventional sedimentation systems could make slurry concentration of between 1 to $3 \%$ TSS (Collet et al., 2011). When higher solid concentrations are required, sedimentation can be adopted as a pre-concentration step combined with other technologies (Gerardo et al., 2015).

\section{Coagulation-flocculation}

The coagulation flocculation is the process of aggregating single cells to larger flocs, thus overcoming the hurdle of repulsion with equicharged particles. The chemical flocculation is carried with the use of inorganic and organic chemical substances. These chemicals are aluminum sulfate, ferric chloride and ferric sulfate in case of inorganic chemicals whereas organic derived compound are polyacrylamide or polyethylene mine. The drawback of chemical flocculants is that the efficacy is influenced by the $\mathrm{pH}$, micro- 
organisms characteristics, water salinity, and biomass concentration. The auto flocculation can also be achieved without use of chemicals at a high $\mathrm{pH}$, typically above 9 , caused by the dissolved carbon dioxide (Van Den Hende et al., 2014). The $\mathrm{pH}$ can be varied by controlling the operating conditions such as supply of air or $\mathrm{CO}_{2}$, which could provide a cost-effective harvesting method. The bio flocculation is a process where other microorganisms (algae, bacteria and fungi) improve the floc forming abilities of the algae in suspension. The principles of cultivation with flocculating micro-organisms may complicate the downstream process and risks of antagonistic interactions, microbial contamination etc. in the harvested biomass (Pearsall et al., 2011).

Electrolytic coagulation (also called electroflocculation) is a physical chemical technique.

The electrodes used in the process releases metal cations that induce coagulation. This process may leave residual metals in the algal concentrate and would affect the quality of byproducts (Patel et al., 2013). The disadvantages of electrolytic coagulation includes, cathode fouling, rise in temperature of the medium, influence of mixing, changes in $\mathrm{pH}$ etc. (Gerardo et al., 2015).

Electro flotation is based on the same principle as electro flocculation in which the cathode is an inactive metal and induces the formation of bubbles due to electrolysis that benefits from not requiring the chemical and only requiring electricity as an input.

\section{Centrifugation}

The recovery of biomass by centrifugation involves the use of the centrifugal force to accelerate the rate of sedimentation. The separation is based on the cell size and density difference between the biomass and the medium. The sedimentation rate is enhanced by the high-speed rotation of the centrifuge that increases the gravity field. The recovered biomass is free from flocculants or chemicals, it can be applied to all strains of microalgae, and high recovery rate and concentrates are easily, predicatively and quickly achieved. The major disadvantage is its high energy requirements.

\section{Flotation}

The flotation uses the low density of microalgae that can float upwards much more rapidly than sediment downwards. Some microalgae naturally float due to the presence of gas vesicles; they include cyanobacteria. The flotation of cell should be of hydrophobic in nature and this could be achieved with the use of surfactants or coagulants. The attachment of air bubbles to the cells depends on many factors including size, probability of collision and adhesion. This process requires generation of micron sized bubbles with the use of dispersed air, micro flotation and froth flotation. It eliminates the requirements of high energy intensive compressor for generating bubbles and foam with the more of surfactant at low pressure spurger (Hanotu et al., 2012).

\section{Filtration}

Harvesting of microalgae cells using filtration systems is based on a solid/liquid separation where a semi-permeable filter acts as a barrier. This barrier contains pores smaller than the cells being retained permitting a selective passage of water, salts, and other soluble substances. The filtration may cause fouling of membrane resulting into pore blocking, and adsorption of gel flocculants such as EOM. Membrane filtration is an effective technology for the harvesting of microalgae; in absence of chemicals which 
does not complicate product extraction from the biomass and culture media. Filter press can reach solid concentrations of up to $25 \%$, though these systems are more likely to be suitable for much bigger size or cylindrical size species (Gerardo, et al., 2014). Considering advantages and constrains related to these harvesting techniques, the study was carried out.

\section{Materials and Methods}

The identified strain Scendesmus sp is grown in FRP race way pond developed for large scale cultivation of microalgae. The developed system has the capacity to grow the algae in 2500 litres of water media. The cultures are added in sufficient quantity i.e $5 \%$ of total volume. The nutrient was supplied in the form of urea and single super phosphate fertilizer along with the micronutrient fertilizer combination. The fertilizer concentration was maintained as per the nutrient level present in the BG-11 medium which was used for the isolation and maintenance of the microalgae culture. The algae were grown in FRP race way pond (Figure 1) for a period of 14-18 days and then harvested. The growth measurement was done by measuring the optical density of samples drawn from tank drawn at different intervals. The depth of water in FRP pond was maintained between 0.2 to $0.3 \mathrm{~m}$. The circulation of culture \& nutrients was maintained using paddle wheel. Fresh water algae grown in $2.5 \mathrm{~m}^{2}$ pond showed a productivity of $0.94 \mathrm{~g} / \mathrm{L}$ after 14 days of growth period.

\section{Studies on Harvesting of Microalgae}

Harvesting of microalgae grown in FRP pond was studied using the chemical flocculation, sedimentation and physical filtration methods. The various harvesting process and their mechanism are summarized in Table 1 . These methods are looked at vigorously because they have the potential to harvest algae with the same efficiency but varied in energy efficiency and production cost.

\section{Chemical flocculation}

The study was conducted to assess the flocculation efficiency of microalgae using different chemicals i.e. Sodium hydroxide $(\mathrm{NaOH})$, Ferric Chloride $\left(\mathrm{FeCl}_{3}\right)$ and alum. The flocculation efficiency was estimated by using the following formula:

Flocculation efficiency $(\%)=\left(1-\frac{A}{B}\right) * 100$

Where, $\mathrm{A}=$ Absorbance after flocculation

$\mathrm{B}=$ Absorbance before flocculation

Absorbance was measured as an optical density using UV-vis-photo spectrometer at frequency of $690 \mathrm{~nm}$.

\section{Harvesting by Electrolytic flocculation Process}

The study was conducted using electrolytic process for harvesting the micro algae. This process requires the use of both physical and chemical stimuli for the effective separation of microalgae biomass. The metal ions released into the solution are metal hydroxides that contribute to the destabilization of colloid suspension and coagulate the biomass. The electrodes consisted of two flate copper metal plates with surface area of $250 \mathrm{~cm}^{2}$, and placed in media solution the anode and cathode were connected to the positive and negative outlet of DC power. The power is supplied by a 12 $\mathrm{V}$ battery during the experimentation. The current density was controlled by changing the current of the DC power supply, which was operated in the constant current mode. The electrode area was kept constant while the current was varied and the volume of the 
microalgae culture was also changed to observe its flocculation and harvesting efficiency. Flocculation is achieved by the linking of the positively charged metal ion to the negatively charged microalgae cells and the movement toward the anode as a result of electrophoresis motion.

\section{Results and Discussion}

\section{Harvesting with Sodium hydroxide}

Flocculation efficiency of microalgae grown in FRP pond was studied by adding in different quantities of $0.5 \mathrm{M} \mathrm{NaOH}$ solution. The efficiency was measured after 30 minute of proper mixing of chemicals. The maximum efficiency was observed to be 37.3 percent with $2.0 \mathrm{ml}$ of $05 \mathrm{M} \mathrm{NaOH}$ solution. The addition of $\mathrm{NaOH}$ increases the $\mathrm{pH}$ of solution up to $10.5 \mathrm{pH}$ which leads to the change in the charge of algal cells and hence leading to its floc formation. The details of result are shown in Table 2.

\section{Harvesting with Ferric chloride}

The study was conducted using different concentration of ferric chloride $\left(\mathrm{FeCl}_{3}\right)$ and varying the quantity of chemicals for harvesting the algae. The study showed that with increasing concentration of $\mathrm{FeCl}_{3}$ flocculation efficiency also increases. Microalgae culture containing no flocculent was used as control.

The flocculation efficiency of $\mathrm{FeCl}_{3}$ sharply increased from $15.44 \%$ to $75.63 \%$ when the dosage increased from $50 \mathrm{ppm}$ to $250 \mathrm{ppm}$ after 30 minutes sedimentation. Therefore, the quantity of ferric chloride was also increased and conducted experiment by varying it from 0.1 to $0.25 \mathrm{~g} / \mathrm{L}$. The study revealed that flocculation and harvesting efficiency increases with the quantity increases The maximum flocculation efficiency was $98.3 \%$ where as the harvesting efficiency was $89.4 \%$ (Table 3).

\section{Harvesting with Alum}

Alum is well known flocculant used for general purpose. It was used as flocculants in different quantities for the flocculation of micro algae. The maximum flocculation efficiency with alum was $93.6 \%$ and harvesting efficiency was $88.2 \%$ at $0.5 \mathrm{~g} / \mathrm{L}$ concentration of Alum (Table 3). Alum was further opted for the harvesting experiments at large scale microalgae growth conditions. Alum has also shown the comparative harvesting efficiency with ferric chloride and sodium hydroxide. Being cheaper and easily available than other flocculants, alum is the effective flocculants for further chemical harvesting experiments.

\section{Filtration of microalgae}

The filtration process was studied for harvesting the microalgae using different types of fabric filters. The air bubbling used during the growth period has shown partial flocculation. The partial flocculants coupled with filtration unit using the fabric film of 400 mesh (Fig. 2) has shown filtration effective varied from 81.6 to $83.0 \%$ (Table 4 ). The filtered water was observed to be suitable for recycling for microalgae growth.

\section{Harvesting by Electrolytic flocculation Process}

The energy requirement for different experimental conditions was assessed (Fig. 4). The energy requirement was found to be lowest in the highest volume size while it is highest in lower volume of microalgae samples. As the volume of the harvesting solution is increased the resistance is also increased due to the presence of higher microalgal cells. Due to increased resistance 
the current has been lowered down leading to the lower energy requirement at higher volume size. The coagulation process is induced by the generation of current from a copper electrode as shown in Figure 3. The microalgal recovery efficiency was determined based upon the decrease in optical density of the microalgal suspension. The difference in harvesting efficiency was found to be slightly vary in all the three volume samples of microalgal culture (Fig. 4).

Table.1 Harvesting methods of microalgae

\begin{tabular}{|c|c|c|c|c|c|}
\hline S.N. & Process & Mechanism followed & $\begin{array}{l}\text { Influence of } \\
\text { algal strains } \\
\text { on process }\end{array}$ & $\begin{array}{l}\text { Solid } \\
\text { conc. } \\
\text { (TSS), \% }\end{array}$ & Energy Input level \\
\hline \multirow[t]{4}{*}{1} & Inorganic Lime & Floc -enmeshment & Minor & $8-10$ & High \\
\hline & Alum & $\begin{array}{l}\text { Floc -enmeshment and } \\
\text { destabilization }\end{array}$ & Minor & $8-10$ & High \\
\hline & Poly-electrolytes & $\begin{array}{l}\text { Floc -enmeshment, } \\
\text { destabilization and bridging }\end{array}$ & Minor & $8-10$ & Medium \\
\hline & Bio-flocculation & Spontaneous flocculation & High & $1-3$ & Low \\
\hline 2 & Centrifugation & Accelerated discrete settling & Minor & $>10$ & High \\
\hline 3 & $\begin{array}{ll}\text { Cross } & \text { Flow } \\
\text { Filtration } & \end{array}$ & $\begin{array}{l}\text { Membrane self } \\
\text { cleaning }\end{array}$ & Minor & $2-6$ & High \\
\hline 4 & Micro straining & Fabric straining & High & $2-4$ & Medium \\
\hline
\end{tabular}

Table.2 Flocculation efficiency with $\mathrm{NaOH}$

\begin{tabular}{|l|c|c|c|c|}
\hline S.No. & $\begin{array}{c}\text { Volume of 0.5 M } \\
\text { NaOH }\end{array}$ & $\begin{array}{c}\text { Initial optical } \\
\text { density }\end{array}$ & $\begin{array}{c}\text { Optical density after } \\
\text { flocculation }\end{array}$ & $\begin{array}{c}\text { Flocculation } \\
\text { efficiency }\end{array}$ \\
\hline 1. & $0.1 \mathrm{ml}$ & 0.332 & 0.328 & 1.20 \\
\hline 2. & $0.5 \mathrm{ml}$ & 0.332 & 0.302 & 9.04 \\
\hline 3. & $1.0 \mathrm{ml}$ & 0.332 & 0.263 & 20.78 \\
\hline 4. & $2.0 \mathrm{ml}$ & 0.332 & 0.208 & 37.35 \\
\hline
\end{tabular}

Table.3 Flocculation efficiency of Alum \& Ferric chloride

\begin{tabular}{|l|c|c|c|c|c|}
\hline S.N. & $\begin{array}{c}\text { Concentration } \\
\text { Flocculants } \\
\text { g/L }\end{array}$ & $\begin{array}{c}\text { Optical density } \\
\text { before } \\
\text { experiment }\end{array}$ & $\begin{array}{c}\text { Optical density } \\
\text { after } \\
\text { flocculation }\end{array}$ & $\begin{array}{c}\text { Flocculation } \\
\text { efficiency } \\
(\boldsymbol{\%})\end{array}$ & $\begin{array}{c}\text { Harvesting } \\
\text { efficiency } \\
(\boldsymbol{\%})\end{array}$ \\
\hline A. & Ferric Chloride & & & & \\
\hline 1. & 0.1 & 0.860 & 0.477 & 44.5 & 63.9 \\
\hline 2. & 0.2 & 0.860 & 0.052 & 93.9 & 88.3 \\
\hline 3. & 0.25 & 0.860 & 0.015 & 98.3 & 89.4 \\
\hline B. & Alum & & & & \\
\hline 1. & 0.25 & 0.860 & 0.279 & 67.6 & 78.7 \\
\hline 2. & 0.50 & 0.860 & 0.055 & 93.6 & 88.2 \\
\hline 3. & 0.75 & 0.860 & 0.067 & 92.3 & 87.9 \\
\hline
\end{tabular}


Table.4 Harvesting of microalgae by filtration processes

\begin{tabular}{|c|c|c|c|c|}
\hline \multirow[t]{2}{*}{ S. No. } & \multirow[t]{2}{*}{ Materials used } & \multicolumn{2}{|c|}{ Optical Density } & \multirow{2}{*}{$\begin{array}{c}\text { Harvesting Efficiency } \\
(\%)\end{array}$} \\
\hline & & Before & After & \\
\hline 1 & Fine cloth & 0.932 & 0.024 & 97.4 \\
\hline 2 & Micro nylon filter cloth & 0.932 & 0.015 & 98.4 \\
\hline 3 & Non woven Fabric cloth & 0.932 & 0.047 & 94.9 \\
\hline
\end{tabular}

Table.5 Flocculation efficiency of microalgae harvesting using alum in the race way pond

\begin{tabular}{|c|c|c|c|c|c|}
\hline $\begin{array}{c}\text { Alum concentration } \\
(\mathbf{g} / \mathbf{L})\end{array}$ & $\begin{array}{c}\text { Quantity } \\
(\mathbf{L})\end{array}$ & $\begin{array}{c}\text { Biomass Recovery } \\
(\mathbf{g})\end{array}$ & \multicolumn{2}{|c|}{ Optical density } & Harvesting \\
efficiency & Before & After & $(\%)$ \\
\hline $\mathbf{0 . 5}$ & 1000 & 390.440 & 0.927 & 0.134 & 85.55 \\
\hline
\end{tabular}

Fig.1 Cultivation of microalgae in FRP raceway pond

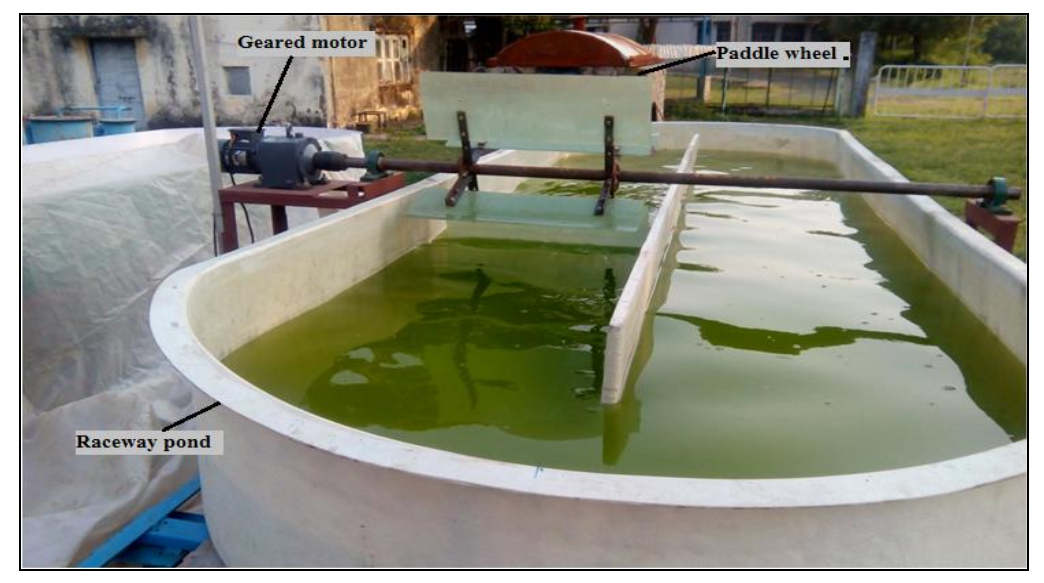

Fig.2 Filtration of microalgae a) Before filtration, b) After filtration using nylon 400 mesh cloth

c) Filtration in the race way pond using nylon 400 mesh cloth

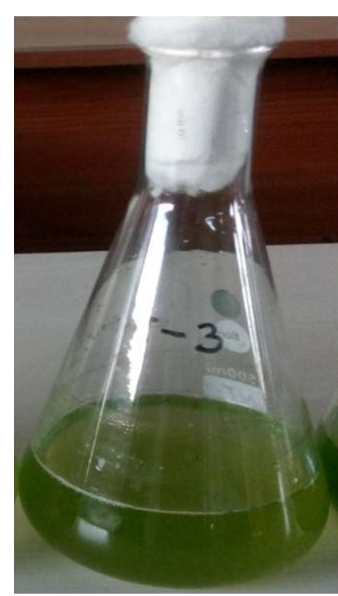

a)

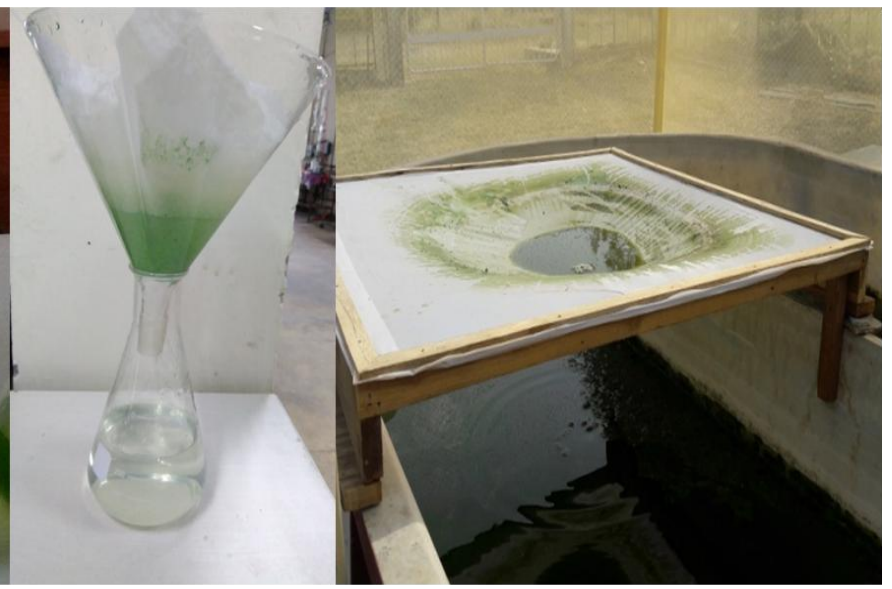

b) c) 
Fig.3 Electrolytic flocculation microalgae harvesting

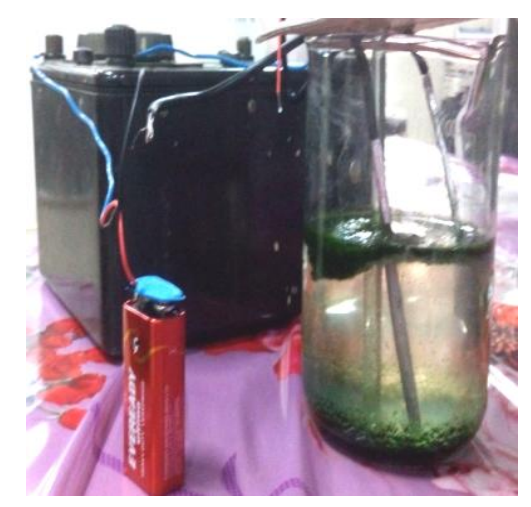

Fig.4 Performance of electrolytic harvesting of microalgae

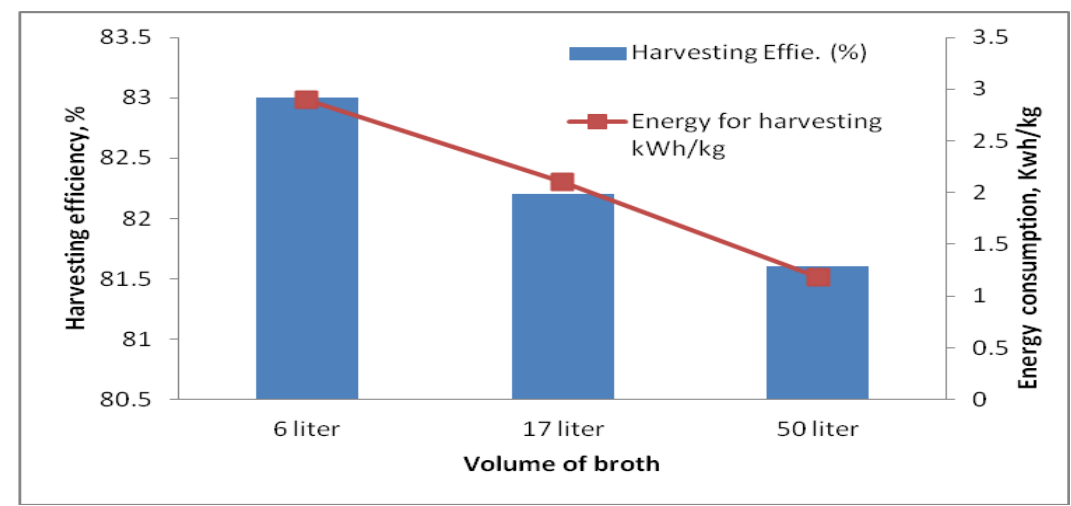

\section{Harvesting of microalgae from FRP pond}

The flocculation of microalgae grown FRP raceway pond was done using alum for harvesting of microalgae. The alum was added at the concentration of $0.5 \mathrm{~g} / \mathrm{l}$ and the harvesting efficiency of alum 85.55 percent was achieved. The productivity of $0.39 \mathrm{~g} / \mathrm{L}$ achieved after growth period of 14 days is presented in Table 5.

\section{Drying of microalgae}

The slurry obtained after harvesting using flocculation and filtration process was dried to achieve moisture content of $5-10 \%$. Scendesmus sp. algae slurry was dried up to $8 \%$ moisture content in a vacuum shelf dryer at a temperature of $50-65{ }^{\circ} \mathrm{C}$. The oven dried algae showed hygroscopic characteristic and porous biomass structure. The open sun drying used for the slurry of microalgae had shown change in texture and color of algal biomass. A solar dryer chamber with black surface and top covered with glass plate, takes 5-6 $\mathrm{h}$ at temperatures $60^{\circ} \mathrm{C}$ to dehydrate the final algal biomass about $4-8 \%$ moisture content. The dried micro alga was analyzed for lipid content of Scendesmus sp. using solvent extraction method.

In conclusion among the inorganic flocculants, ferric chloride and alum had shown the comparable flocculation efficiencies of 88.3 and 88.2 percent respectively. Alum is cost effective compared to other chemical at large scale. The initial study of harvesting of microalgae showed that auto flocculation using fine air bubbles followed by filtration showed more promising 
as compared to chemical flocculation method; however it took 3 to 4 hours. The microalgae harvested using electrolytic method has shown energy consumption between 1.18 $2.9 \mathrm{kWh} / \mathrm{kg}$ of dry microalgae biomass showing lower energy consumption at higher harvesting volumes. The lab scale electrolysis process showed contamination and hence needs further refinement in the electrolysis process for its application at large scale.

\section{Acknowledgements}

The authors are highly thankful to the Director, Central Institute of Agricultural Engineering, Bhopal for allowing the study and also to the Consortia Research platform on Energy from Agriculture (CRP on EA) scheme of Indian Council of agricultural research for providing the funding for research.

\section{References}

Borowitzka, M. 2013. High-value products from microalgae their development and commercialisation, J. Appl. Phycol. 25: 743-756.

Brennan, L. and Owende, P. 2010. Biofuels from microalgae - $\mathrm{a}$ review of technologies for production, processing, and extractions of biofuels and coproducts, Renewable and Sustainable Energy Reviews 14: 557-577.

Collet, P., Hélias, A., Lardon, L., Ras, M., Goy, R. A. and Steyer, J.-P. 2011. Lifecycle assessment of microalgae culture coupled to biogas production, Bioresour. Technol. 102: 207-214.

Danquah M.K., Ang, L., Uduman, N., Moheimani, N. and Forde, G.M. 2009. Dewatering of microalgal culture for biodiesel production: exploring polymer flocculation and tangential flow filtration, Journal of Chemical Technology and Biotechnology 84:
1078-1083.

Gerardo, L., Van Den Hende, S., Han, V., Thea, C. and Stephen C. 2015. Skill, Harvesting of microalgae within a biorefinery approach: A review of the developments and case studies from pilot-plants, Elsevier, Algal Research 11: 248-262.

Gerardo, M.L., Oatley-Radcliffe, D.L. and Lovitt, R.W. 2014. Integration of membrane technology in microalgae biorefineries, J. Membr. Sci. 464: 8699.

Grima, E. M., Belarbi, E.H., Fernandez F.G., Medina, A. R. and Chisti, Y. 2003. Recovery of microalgal biomass and metabolites: process options and economics, Biotechnology Advances 20: 491-515.

Lehmonen, J., Retulainen, E., Paltakari, J. et al., 2019. Dewatering of foam-laid and water-laid structures and the formed web properties. Cellulose 27, 11271146. https://doi.org/10.1007/s10570019-02842-x

Li, Q., Du, W. and Liu, D.H. 2008. Perspectives of microbial oils for biodiesel production, Applied Microbiology and Biotechnology. 80: 749-756.

Monteiro, C.M., Castro, P.M.L. and Malcata, F.X. 2012. Metal uptake by microalgae: underlying mechanisms and practical applications, Biotechnol. Prog. 28: 299311.

Olaizola, M. 2000. Commercial production of astaxanthin from Haematococcus pluvialis using 25,000-liter outdoor photobioreactors, J. Appl. Phycol. 12: 499-506.

Patel, A.K., Laroche, C., Marcati, A., Ursu, A.V., Jubeau, S., Marchal, L., Petit, E., Djelveh, G. and Michaud, P. 2013. Separation and fractionation of exopolysaccharides from Porphyridium cruentum, Bioresour. Technol. 145: 
345-350.

Pearsall, R.V., Connelly, R.L., Fountain, M.E., Hearn, C.S., Werst, M.D., Hebner, R.E. and Kelley, E.F. 2011. Electrically dewatering microalgae, Dielectrics and Electrical Insulation, IEEE Trans. 18: 1578-1583.

Schenk, P., Thomas-Hall, S., Stephens, EMarx,. , U., Mussgnug, J. and Posten, C. 2008. Second generation biofuels: high-efficiency microalgae for biodiesel production, Bioenergetics Research 1: 20-43.

Uduman, N., Qi, Y., Danquah, M. K., Forde, G.M. and Hoadley, A. 2010.
Dewatering of microalgal cultures: a major bottleneck to algae-based fuels, Journal of Renew-able and Sustainable Energy 1 (2): 2-15

Van Den Hende, S., Beelen, V., Bore, G., Boon, N. and Vervaeren, H. 2014. Upscaling aquaculture wastewater treatment by microalgal bacterial flocs: from lab reactors to an outdoor raceway pond, Bioresour. Technol. 159: 342-354.

Wang, B., Li, Y., Wu, N. and Lan, C. 2008. $\mathrm{CO}_{2}$ bio-mitigation using microalgae, Applied Micro-biology and Biotechnology. 79: 707-718.

\section{How to cite this article:}

Anil K. Dubey, Swapnaja K. Jadhav, Ankur Nagori, Mayuri Gupta, Parmanand Sahu and Sujata Tayade. 2020. Studies on Fresh Water Microalgae Harvesting Systems for Bio Fuel. Int.J.Curr.Microbiol.App.Sci. 9(12): 3016-3025. doi: https://doi.org/10.20546/ijcmas.2020.912.357 